\title{
Józef Wroceński
}

\section{Kościół partykularny a Instytuty Życia Konsekrowanego i Stowarzyszenia Życia Apostolskiego}

Prawo Kanoniczne : kwartalnik prawno-historyczny 44/1-2, 47-69

2001

Artykuł został zdigitalizowany i opracowany do udostępnienia w internecie przez Muzeum Historii Polski w ramach prac podejmowanych na rzecz zapewnienia otwartego, powszechnego i trwałego dostępu do polskiego dorobku naukowego i kulturalnego. Artykuł jest umieszczony w kolekcji cyfrowej bazhum.muzhp.pl, gromadzącej zawartość polskich czasopism humanistycznych i społecznych.

Tekst jest udostępniony do wykorzystania w ramach dozwolonego użytku. 
Prawo Kanoniczne

44 (2001) nr 1-2

\section{KS. JÓZEF WROCEŃSKI SCJ}

\section{KOŚCIÓŁ PARTYKULARNY A INSTYTUTY ŻYCIA KONSEKROWANEGO I STOWARZYSZENIA ŻYCIA APOSTOLSKIEGO}

Treść: Wstęp. - 1. Podstawy teologiczno-prawne wzajemnych odniesień. 1.1. Natura Kościola partykularnego. 1.2. Specyfika instytutów życia konskrowanego i stowarzyszeń życia apostolskiego. 1.3. Egzempcja. 1.4. Sluszna autonomia. 1.5. Konieczność wzajemnej wspólpracy - 2. Ważniejsze kwestie szczególowe. 2.1. Zakładanie i znoszenie instytutów życia konsekrowanego i stowarzyszeń życia apostolskiego, prowincji oraz domów. 2.2. Działalność apostolska. 2.3 Problem prezentacji. 2.4. Inne obszary zależności i współpracy. Zakończenie.

\section{Wstęp}

Wzajemne relacje między Kościołem partykularnym a instytutami życia konsekrowanego i stowarzyszeniami życia apostolskiego oraz ich kanoniczna forma podlegały zmianom zależnym od warunków czasu. W niektórych okresach historii Kościoła relacje owe nacechowane były swoistymi napięciami, a również i dzisiaj rodzą praktyczne kolizje kompetencyjne biskupów i przełożonych zakonnych. Dowodzi tego chociażby historia instytucji egzempcji, obecnie zaś przede wszystkim kwestia „słusznej autonomii”. Zagadnienie relacji między Kościołem partykularnym a instytutami życia konsekrowanego i stowarzyszeniami życia apostolskiego zostało podjęte przez Sobór Watykański II', a następnie prawodawstwo posoborowe ${ }^{2}$, Ko-

\footnotetext{
' Por. Konstytucja Lumen Gentium; Konstytucja Gaudium et spes; Dekret Christus Dominus; Dekret Perfectae caritatis; Dekret Apostolicam auctositatem; Dekret Ad gentes divinitus; Dekret Presbyteronim Ordinis.

${ }^{2}$ Por. Pawel VI, Motu proprio Ecclesiae Sanctae, AAS 58/1966/757-787, tekst polski: PPK, t. I, z. 1, s. 110-123; Paweł VI, Adhortacja Ap. Evangelica testificatio, AAS 63/1971/497-526: tekst polski w: Paweł VI, Charyzmat żcia zakonnego. Przemówienia i dokumenty, Poznań-Warszawa 1974; SCRIS-SCE, Notae Directivae Mutuae realtiones, AAS 70/1978/473-506, tekst polski: PPK, t. XI, z. 1, s. 31-96.
} 
deks Prawa Kanonicznego ${ }^{3}$ i inne dokumenty Stolicy Apostolskiej".

Problem ten - skomplikowany i wieloaspektowy - wciąż budzi zainteresowanie kanonistów. Jest to również zagadnienie obszerne, i nie sposób tutaj szczególowo omówić wszystkie związane z nim kwestie. Nie pomniejszając znaczenia żadnej z nich, zamierzam skoncentrować się na dwóch istotnych sprawach. Najpierw należałoby wskazać na podstawy teologiczno-prawne wzajemnych odniesień, a następnie omówić ważniejsze kwestie szczegółowe.

\section{Podstawy teologiczno-prawne wzajemnych odniesień}

Analizę relacji między Kościołem partykularnym a instytutami życia konsekrowanego i stowarzyszeniami życia apostolskiego powinno poprzedzać przedstawienie zalożeń doktrynalnych. Należy więc przyjrzeć się pogłębionemu rozumieniu natury Kościoła, w tym Kościoła partykularnego, oraz roli biskupów zarówno w plaszczyźnie ich działań indywidualnych, jak i kolegialnych. Powinno to pomóc $w$ sformulowaniu praktycznych norm dotyczących współpracy oraz współdziałania biskupów i przełożonych instytutów życia konsekrowanego w życiu i działaniu współczesnego Kościoła.

\subsection{Natura Kościola partykularnego}

W bliższym określeniu natury Kościoła partykularnego należy odwołać się do eklezjologii Soboru Watykańskiego II naświetlającej w sposób pełniejszy naturę jednego i jedynego Kościoła Chrystusowego. W świetle tej eklezjologii Kościól, będący w swej istocie tajemnicą, w której uobecnia się i ujawnia działanie calej Trójcy św., jest wybranym Ludem Bożym, wspólnotą - i to wspólnotą bosko-ludzką, w całości zależną od Boga i ściśle z Nim związaną. Stanowi ona znak i narzędzie zjednoczenia z Bogiem i znak jedności całego rodzaju ludzkiego ${ }^{5}$. W momencie zaistnienia Kościoła powstał na świecie „nowy lud”, który - ożywiony przez Ducha św. -

${ }^{3}$ Por. Wyminieć tu należy zwłaszcza kan. 576; 589; 590; 591; 608; 609; 611; 673-683; 733; 738.

${ }^{4}$ Por. Jan Paweł II, Adhortacja Ap. Pastores dabo vobis, Libreria Editrice Vaticana 1992; SCE, Dyrektorium o postudze i życiu kaplanów, Typis Polyglottis Vaticanis 1973.

${ }^{5}$ Por. Konstytucja Lumen Gentium, nr 1-4. 
jednoczy się w Chrystusie, aby dojść do Ojca'. Członkowie tego ludu, powolani ze wszystkich narodów, są zespoleni ze sobą tak ściśle, że jedności owej nie da się całkowicie ująć i wyjaśnić w kategoriach tylko socjologicznych, właściwych dla elementów socjologiczno-prawnych konstytuujących społeczności świeckie?.

Rzeczywistość wspólnoty kościelnej jest konsekwencją chrześcijańskiego powolania i realizacji wspólnie $z$ Chrystusem dzieła zbawienia. Lud Boży łączą więc daleko mocniejsze i głębsze więzy niż te, które obserwujemy w ludzkich organizacjach. Zasadnicza różnica polega na tym, że wspólnoty ludzkie połączone są tylko takimi więzami, które same potrafią wytworzyć. Wspólnota kościelna tymczasem już ze swej istoty i od samego początku zostala wyposażona w więzy, niejako „odgórnie”", niezależnie od woli jej członków. Aktywność członków wspólnoty kościelnej może wpływać na pełniejsze ujawnienie się tych związków, ale nie jest ona ich źródłem. Kościół jako wspólnota posiada zdolność tworzenia organicznej syntezy różnych warstw swej rzeczywistości, co z kolei wpływa na sformulowania normatywne. Podobnie więc jak Chrystus - wzór jedności - ma naturę bosko-ludzką, tak też wspólnota kościelna przez Niego zainicjowana i realizowana zawiera w sobie nie tylko elementy w pełni ludzkie /indywidualne i społeczne/, lecz także elementy boskie, w sposób sobie dostępny i właściwy.

Wspólnotę Kościoła można określić w sposób syntetyczny jako rzeczywistość głębokich i wielorakich życiowych więzi międzyosobowych, wywodzących się $z$ uczestnictwa w zbawczej tajemnicy Chrystusa ${ }^{8}$. Są to najpierw więzy natury ontycznej, ponieważ rodzą u członków wspólnoty nową, nadprzyrodzoną egzystencję, a także natury dynamicznej, gdyż wyznaczają rytm działania tej wspólnoty. Z pozytwynej woli Chrystusa owa komunia członków Ludu Bożego nie wyczerpuje się w relacjach indywidualnych, międzyosobowych, lecz polega również na współzjednoczeniu mniejszych i większych wspólnot w wymiarze horyzontalnym i wertykalnym. Nie dokonuje się też ona na równej plaszczyźnie, ale jest zjednoczeniem organicznie $\mathrm{i}$ hierarchicznie ukonstytuowanym, polączonym $\mathrm{z}$ istnie-

${ }^{6}$ Por. Ef. 2,18.

'Por. Mutuae relationes $/ \mathrm{MR} / \mathrm{n} .1$.

${ }^{8}$ Por. J. Wroceński, Rola i zadania prezbiterium w życiu Kościoła partykulamego, Warszawa 1998, s. 181-184. 
niem rozmaitych posług, funkcji i charyzmatów. Jest w niej także miejsce dla instytutów życia konsekrowanego i stowarzyszeń życia apostolskiego. Zakonnicy włączeni we wspólnotę Kościoła i w jego zbawcze posłannictwo nie są kimś pośrednim pomiędzy duchownymi i wiernymi świeckimi, lecz z jednych i drugich Bóg powoluje niektórych chrześcijan, aby w życiu Kościoła korzystali ze szczególnego daru", jakim jest życie zakonne. Należy ono do życia i świętości Kościoła $^{10}$. Wizja Kościoła złożonego jedynie z szafarzy i wiernych świeckich nie odpowiada zamiarom Boskiego Założyciela, jakie możemy odczytać z Ewangelii i innych pism Nowego Testamentu ${ }^{11}$.

Instytuty życia konsekrowanego i stowarzyszenia życia apostolskiego włączone są więc integralnie w Kościól Chrystusowy i w jego misję. Dlatego też cieszą się jego poparciem i opieką, a także podlegają koordynowanej przez tenże Kościół - zarówno w jego strukturach uniwersalnych jak i lokalnych - działalności pastoralnej ${ }^{12}$. Działalność ta oparta jest na misji pasterskiej św. Piotra i Apostołów oraz ich następców - papieża i biskupów, w wymiarze indywidualnym i kolegialnym. Stąd też instytuty życia konsekrowanego oraz ich dzialalność apostolska poddane zostały władzy biskupów - jako pierwotnych i najbardziej autorytatywnych inspiratorów i koordynatorów tejże działalności na podległym sobie terytorium kościelnym ${ }^{13}$. Z woli Chrystusa św. Piotr zostal postawiony nad innymi Apostolami i w nim Chrystus ustanowil trwałą i widzialną zasadę oraz fundament jedności i wspólnoty ${ }^{14}$. A zatem następca św. Piotra - papież - jest najwyższym Pasterzem całego Ludu Bożego oraz najwyższym przełożonym wspólnot zakonnych ${ }^{15}$. Pozostali zaś biskupi pozostający w hierarchicznej wspólnocie z papieżem i tworzący wraz z nim Kolegium Biskupów są również w sposób szczególny odpowiedzialni za misję Kościoła i wypełnianie jego zbawczego posłannictwa ${ }^{16}$.

${ }^{9}$ Por. Konstytucja Lumen Gentium, n. 43.

"Por. KPK, kan. $574 \$ 1$.

${ }^{11}$ Por. Jan Paweł II, Adhortacja Ap. Vita consecrata, n. 29.

${ }^{12}$ Por. F. St. Pasternak, Ordynariusz miejsca a wspólnoty zakonne w nowym prawie kanonicznym, w: Duszpasterstwo w świetle nowego Kodeksu Prawa Kanonicznego/praca zbiorowa pod red. J. Syryjczyka/, Warszawa 1985, s. 96.

${ }_{13}$ Por. Tamże.

${ }^{14}$ Por. Konstytucja Lumen Gentium, n. 18.

${ }^{15}$ Por. KPK, kan. $590 \$ 1$.

${ }^{16}$ Por. Konstytucja Lumen Gentium, n. 20. 
Kościół - jeden i jedyny w swej istocie - posiada wiele możliwych sposobów realizacji swej misji, istnieje też i działa w wielu partykularnych formach. Każda $z$ owych form zawiera tę samą co do istoty rzeczywistość Kościoła, ponieważ w nich jest obecny Chrystus, właściwy sprawca tej rzeczywistości. Dzięki temu każda jest Kościołem, Kościołem partykularnym. Można to wyrazić w postaci pewnego sylogizmu: Jeden i jedyny Kościół Chrystusowy istnieje i działa w wielu Kościołach partykularnych - wiele Kościołów partykularnych zawiera tę samą rzeczywistość jednego i jedynego Kościoła Chrystusowego - jest więc wiele Kościołów partykularnych, ale jeden i jedyny jest Kościół Chrystusowy, ten sam we wszystkich Kościolach $^{17}$. Kościół partykularny to przede wszystkim diecezja ${ }^{18}$, w której w osobie biskupa diecezjalnego realizuje się w wymiarze indywidualnym wspomniana wyżej odpowiedzialność pasterska. Dzieje sią tak ponieważ biskup stojący na czele Kościola partykularnego jest pasterzem-własnym, zwyczajnym i bezpośrednim ${ }^{19}$, a więc nie delegowanym przez autorytet zwierzchni i nie działającym w imieniu tego autorytetu, lecz mocą swego urzędu i na stałe. Mówi o tym kan. 381, w którym prawodawca stwierdza: „Biskupowi diecezjalnemu w powierzonej mu diecezji przysługuje wszelka władza zwyczajna, własna $\mathrm{i}$ bezpośrednia, jak jest wymagana do jego pasterskiego urzędu, $z$ wylączeniem tych spraw, które na mocy prawa lub dekretu Papieża są zarezerwowane najwyższej lub innej władzy kościelnej". Wspomnianej władzy biskupa podlegają także zakonnicy i członkowie stowarzyszeń życia apostolskiego, tworząc wraz z kapłanami diecezjalnymi prezbiterium Kościoła partykularnego, szczególnie w zakresie swojej pracy apostolskiej i powołania kapłańskiego.

Z przytoczonych wyżej założeń doktrynalnych Soboru Watykańskiego II oraz Kodeksu Prawa Kanonicznego wynika, że instytuty życia konsekrowanego i stowarzyszenia zycia apostolskiego są w sposób organiczny związane $z$ naturą Kościoła i dzięki temu zostały włączone integralnie w misję apostolską Kościoła. Podlegają więc tym kościelnym strukturom hierarchicznym, które za tę misję

${ }^{17}$ Por. St. Napierala, Pojęcie Kościola partykulamego $w$ dokumentach Soboru Watykańskiego II, Poznań 1985, s. 75-76.

${ }^{18}$ Por. KPK, kan. $368 \$ 1$.

19 Por. KPK, kan. $381 \S 1$. 
są przede wszystkim odpowiedzialne: Biskupowi Rzymskiemu i Stolicy Apostolskiej oraz Kolegium Biskupów w wymiarze uniwersalnym, a także Konferencjom Biskupów i biskupom diecezjalnym w wymiarze partykularnym w porozumieniu $\mathrm{z}$ kompetentnymi władzami zakonnymi. Jednak zakres owej zależności modyfikowany jest przez autonomię własnego, wypróbowanego przez władzę kościelną posłannictwa, w ramach zatwierdzonych przez Kościól Konstytucji. Praktyka rad ewangelicznych i przyznana instytutom życia konsekrowanego przez prawo słuszna autonomia decydują o ich specyfice oraz o szczególnym sposobie uczestnictwa w naturze Ludu Bożego. To z kolei wplywa na właściwe rozumienie wzajemnych relacji między Kościołem partykularnym a instytutami życia konsekrowanego i stowarzyszeniami zycia apostolskiego.

\subsection{Specyfika instytutów życia konsekrowanego i stowarzyszeń życia apostolskiego}

Mówiąc o specyfice instytutów należy odwołać się do samej natury życia konsekrowanego, które się w nich realizuje. Obszerną definicję życia konsekrowanego ukazującą jego teologiczne elementy znajdujemy w kan. $573 \$ 1 \mathrm{KPK}$. W paragrafie drugim przywołanego kanonu prawodawca, wymieniając elementy prawne życia konsekrowanego, wskazuje na istotę instytutów, tj. stałość, kanoniczną erekcję dokonaną przez kompetentną wladzę kościelną, wolny wybór tej formy życia, podjęcie rad ewangelicznych na podstawie świętych więzów oraz zachowanie prawa własnego.

$\mathrm{Z}$ treści cytowanego kanonu można wnioskować, że o specyfice instytutów życia konsekrowanego oraz stowarzyszeń życia apostolskiego stanowi przede wszystkim praktyka rad ewangelicznych, która w poszczególnych instytutach jest regulowana prawem własnym, a także inne właściwości bliżej określające ową specyfikę, w tym charyzmat i patrimonium. Jeśli zaś chodzi o patrimonium to prawodawca w kan. 578 wyliczył aż pięć jego elementów składowych, mianowicie: natura, cel, duch, charakter, zdrowe tradycje.

Rady ewangeliczne, podejmowane dobrowolnie, ułatwiają dążenie do osobistej doskonałości i prowadzą do doskonałej miłości w naśladowaniu Chrystusa ${ }^{20}$. W Kościele istnieje wiele sposobów

${ }^{20}$ Por. J. R. Bar, Prawo zakonne po Soborze Watykańskim II, Wąrszawa 1977, s. 12. 
rcalizacji powolania opartego na praktyce rad ewangelicznych /instytuty zakonne, świeckie, stowarzyszenia życia apostolskiego/, co podkreśla wielość dróg wiodących do doskonałości²1. Należy jednak zauważyć iż prawodawca na mocy kan. 576, wprowadził większy i rozleglejszy w porównaniu z poprzednim Kodeksem wgląd kompetentnej władzy kościelnej / tzn. Stolicy Apostolskiej, w przypadku instytutów na prawie papieskim oraz Ordynariusza miejsca w przypadku instytutów na prawie diecezjalnym/ w kwestię interpretacji rad ewangelicznych i ich praktykę w konkretnych warunkach życia. Władze te mają też troszczyć się o to, aby instytuty były wierne swojej własnej specyfice, określonej konstytucjami.

Chociaż Sobór Watykański II nie określił życia konsekrowanego mianem charyzmatu, to jednak polożył szczególny nacisk na zachowanie charyzmatu założycieli oraz pierwotnej tradycji danego instytutu. Członkowie instytutu mają żyć z nimi w zgodzie, strzec swojej spuścizny duchowej, pogłębiać ją i nieustannie dostosowywać do aktualnych warunków kulturalnych i społecznych, czyli rozwijać ją $\mathrm{w}$ harmonii $\mathrm{z}$ życiem Kościola powszechnego i partykularnego ${ }^{22}$. Realizacja charyzmatu jest - oprócz praktyki rad ewangelicznych jedną z form naśladowania Chrystusa, decyduje ona również o różnorodności poszczególnych instytutów i o ich specyfice. Kodeks Prawa Kanonicznego nie używa wprawdzie terminu „charyzmat”, występuje on jednak w dokumentach soborowych, a także znajdowal się w schematach Kodeksu ${ }^{23}$ oraz spotykamy go w dokumentach pokodeksowych ${ }^{24}$. Pominięcie tego terminu w Kodeksie wydaje się nieuzasadnione w kontekście nauki soborowej.

$\mathrm{Z}$ charyzmatem wiążą się ściśle inne elementy dziedzictwa duchowego instytutu, określane mianem patrimonium. Zawartość treścio-

${ }^{21}$ Por. M. Zurowski, Spoteczności realizacji rad ewangelicznych w "komunii" Kosciola partykulamego, Prawo Kanoniczne 25/1982/ nr 1-2, s. 127.

${ }^{22}$ Por. Tamże, s. 128.

${ }^{23}$ Por. Por. Schemat 1977 , kan. $89 \S 1$; Schemat 1980, kan. 506, $516 \S 3,557 \S 1$, $634,642 \S 1,643 \S 3,648 \S 1-2$; Schemat 1982 , kan. $580,590 \S 3,631 \S 1,708,716$ $\$ 1,717 \S 3,722 \$ 1-2$. Warto podkreślić, że w dwóch ostatnich schemtach posługiwano się zarówno terminem „charyzmat”, jak i „patrimonium”, używając ich często łącznie.

${ }^{24}$ Por. SCRIS, Potissimum institutionis, AAS 82/1990/470- 532; Synod Biskupów, Zycie konsekrowane i jego postannictwo w Kościele i świecie. Instrumentum laboris, Watykan 1994; SCRIS, Congregavit nos in unum, Enchiridion Vaticanum t. 14, s. $220-283$. 
wa tego pojęcia jest szeroka, a dokładne jej określenie wcale nie należy do zadań łatwych ${ }^{25}$. Nie wchodząc w szczegóły, należy zauważyć tylko, że obecnie daje się obserwować bardzo duże zróżnicowanie poglądów w kwestii rozumienia charyzmatu i patrimonium instytutu. Dotąd nie ma w kanonistyce „opinio communis” w tym przedmiocie, a lektura dokumentów bezsprzecznie potwierdza bliskoznaczność obu terminów i ścisłą zależność między nimi. Stwierdza się wręcz, iż charyzmat kształtuje i określa patrimonium instytutu ${ }^{2 \hbar}$.

Pozostawiając na uboczu kwestie terminologii, warto zauważyć, że ów specyficzny charakter posłannictwa każdego instytutu wyraża się nie tylko w swoistym stylu uświęcania, ale i w sposobach apostolowania, popartych często tradycją danego instytutu. Pielęgnowanie tych odrębności i posłannictwa właściwego danego instytutu oraz jego charakteru wymaga - zwłaszcza współcześnie - szczególnej troski /także ze strony biskupów/, by nie narażać instytutów na zacieranie ich specyfiki w trakcie włączania instytutów w życie i działalność Kościoła ${ }^{27}$. Zakonnicy powołani są w Kościele przede wszystkim do tego, by własnym życiem dawali jawne świadectwo pełnego oddania się Bogu, by ubogacali cały Kościół własną duchowością i posłannictwem, a w ten sposób wnosili własny wkład w budowanie wspólnoty Ludu Bożego. Wyraźnym znakiem troski Kościoła o zachowanie specyfiki zwlaszcza instytutów życia konsekrowangeo i ochronę ich dziedzictwa było przyznawanie niektórym $\mathrm{z}$ nich tzw. prawa egzempcji. Przechodząc do omówienia aktualnego rozumienia pojęcia egzempcji należy zauważyć, że ta prastara instytucja prawna w przeszłości niewątpliwie pomagała instytutom w zachowaniu wlasnej odrębności. Obecna jednak jej regulacja oceniana bywa poniekąd jako martwa litera prawa.

\subsection{Egzempcja}

Instytucji egzempcji, rozumianej jako uwolnienie instytutu życia konsekrowanego spod kierownictwa ordynariusza miejsca, prawodawca poświęcił wprawdzie jedynie kanon 591, ale jego zamiesz-

${ }^{25}$ Szerzej na ten temat por. B. Szewczul, Troska Kościota o zachowanie patrimonium przez instytuty życia konsekrowanego na podstawie dokumentów kościelnych $z$ lat 1917-1996, Warszawa 1999, mps, s. 54-105.

${ }_{26}$ Por. Jan Pawel II, Adhortacja Ap. Vita consecrata, n. 36.

${ }^{27}$ Por. F. St. Pasternak, Wzajemne relacje między biskupami i zakonnikami w Kosciele posoborowym, Prawo Kanoniczne 22/1979/ nr 3-4, s. 90. 
czenie w Kodeksie świadczy o utrzymaniu w Kościele tej instytucji prawnej. Wspomniany kanon w zasadniczej swej treści został zaczerpnięty z Konstytucji Lumen Gentium ${ }^{28}$, ale również inne dokumenty soborowe $\mathrm{e}^{29} \mathrm{i}$ posoborowe $\mathrm{e}^{311}$ podejmowały zagadnienie egzempcji. Jak wynika $z$ tekstów dokumentów, instytucja ta może sprzyjać zachowaniu patrimonium, ponieważ ma służyć zachowaniu $\mathrm{w}$ instytutach ladu wewnętrznego $\mathrm{i}$ harmonii, a tym samym przyczyniać się do ich większego dobra, rozwoju i doskonałości. Ma ona też na celu lepsze wyrażanie tożsamości instytutów. Wspomniane wyżej źródła nadmieniają, że egzempcja służy jednocześnie pożytkowi Kościoła, bowiem nie oznacza całkowitego uniezależnienia się od jurysdykcji ordynariusza miejsca, lecz dotyczy głównie spraw wewnętrznych instytutu.

Pomimo tych wyjaśnień trudno jednak powiedzić, jaką rzeczywistą wartość ma norma kan. 591, ponieważ prawodawca nie określił dokładnie, czym jest egzzempcja, kogo dotyczy i jakie pociąga za sobą skutki prawne. Ponadto istniejące instytuty na prawie papieskim znajdują się w podobnej styuacji prawnej co dawniej instytuty cieszące się egzempcją. Różnica pomiędzy „wyjętymi” i „niewyjętymi” instytutami kleryckimi na prawie papieskim obecnie jest już prawie niewidoczna ${ }^{31}$. W tej sytuacji należy przyjąć, że bardziej precyzyjnie warunki egzempcji określa papież w samym akcie, na mocy którego instytut zostaje wyjęty spod zależności od biskupa, określonej prawem powszechnym ${ }^{32}$. A zatem możliwa jest egzempcja w. szerszym tego słowa znaczeniu aniżeli stosowana do wszystkich instytutów na prawie papieskim, jednakże wymaga to osobistej interwencji papieża, którą powinien On podjąć czy to ze względu na dobro instytutu, czy też $\mathrm{z}$ troski o zabezpieczenie potrzeb apostolatu ${ }^{33}$. W związku $\mathrm{z}$ tym pojawiają się w środowisku kanonistów głosy twierdzące, że definicja egzempcji jest nadal kwestią kluczową w przypadku anali-

\footnotetext{
${ }^{28}$ Por. N. 45.

${ }^{29}$ Por. Dekret Christus Dominus, n. 35.

3o Por. Schemat 1977, kan. 519; Mutuae relationes, n. 22.

${ }^{31}$ Por. R. Henseler, Podstawowe refleksje nad stosunkiem Kościót partykularny - instytuty zakonne, w: Autonomia zakonów a Kościół partykularny, Lublin 1991, s. 23.

${ }_{32}^{32}$ Por. De Paolis, La vita consacrata nella chiesa, Bologna 1992, s. 135.

${ }^{3}$ Por. M. Al. Zurowski, Biskup diecezjalny a wyższy przelożony zakonny instytutu zycia konsekrowanego, Prawo Kanoniczne 27/1984/ nr 3-4, s. 36.
} 
zowania stosunku między Kościołem partykularnym a instytutami życia konsekrowanego. Spotyka sią również przekonanie, że ani instytucja autonomii, ani właściwość „bycia” na prawie papieskim nie zastępują nawet w przybliżeniu tego, czym egzempcja byla. Stąd też nawet przy zachowaniu soborowych przesunięć akcentu musi pozostać w systemie prawa kościelnego. Niektórzy kanoniści wręcz ubolewają, że pozycja biskupa stała się bardzo silna, a tym samym nastąpila daleko idąca eliminacja instrumentu egzempcji ze sfery stosunków między Kościołem partykularnym a instytutami, poszukiwanie zaś rzekomo nowej gwarancji zachowania własnej odrębności i dopatrywanie się jej w autonomii nie ma większego sensu ${ }^{34}$. Argumentem uzasadniającym tego rodzaju przekonanie jest kan. 586, zgodnie z którym autonomia odnosi się do życia, wewnętrznego zarządzania, dziedzictwa duchowego oraz wlasnej dyscypliny instytutu. Temu jednak sprzeciwia się fakt, że instytuty poddane są w pełni władzy biskupów diecezjalnych w sprawach duszpasterstwa, publicznego wykonywania kultu Bożego, wykonywania innych dziel apostolskich, przede wszystkim zaś w kwestii koordynacji tych spraw w diecezji ${ }^{35}$.

Z kolei inni kanoniści zauważają, że obecnie wielkie dobrodziejstwo egzempcji i prawo niezależności, jakie ona niesie ze sobą, nie są w pełni doceniane. Dzieje się tak z powodu nieznajomości prawa własnego instytutu przez jego członków, szczególnie prawa dość odległego w czasie, sięgającego początków instytutu, kiedy to wraz $\mathrm{z}$ fundacją instytutu wyjętego przyznano mu jednocześnie w ramach egzempcji szereg praw. Pojawia się więc nagląca potrzeba studiowania własnych źródeł i poznania zakresu egzempcji instytutu, aby następnie można było chronić egzempcję jako istotną dla życia i działalności instytutu, a tym samym jako siłę witalną w służbie Kościołowi ${ }^{36}$.

Normę kan. 591 należy więc interpretować z uwzględnieniem innych norm, do których należą: prawo własne, słuszna autonomia wszystkich instytutów oraz zrównanie w prawach wyjętych i niewyjętych instytutów kleryckich i stowarzyszeń życia apostolskiego na prawie papieskim. Trzeba również brać pod uwagę i to, że biskup

\footnotetext{
${ }^{34}$ Por. R. Henseler, Podstawowe refeleksje..., s. 24-27.

${ }^{35}$ Por. KPK, kan. $394 \$ 1 ; 678 \S 1$ i 680 . Szerzej na ten temat R. Henseler, Podstawowe refleksje..., s. 27.

${ }^{36}$ Por. J. Beyer, Il diritto della vita consacrata, Milano 1989, s. 110-112.
} 
koordynuje wszelkie prace apostolskie w swojej diecezji w celu zachowania jedności zarządzania Kościołem partykularnym.

\subsection{Sluszna autonomia}

Instytucja autonomii instytutów życia konsekrowanego i stowarzyszeń życia apostolskiego pojawila się po Soborze Watykańskim II w wyniku doświadczeń związanych z procesem odnowy życia zakonnego i jest przejawem troski Kościoła o dziedzictwo instytutów, zwłaszcza duchowe. Nie brak jednak głosów twierdzących, iz jest ona zjawiskiem znanym w kościelnym prawie o stowarzyszeniach, zastosowanym obecnie w sposób wyraźny, choć wcale nie nowy do prawa zakonnego. Autonomia przeniesiona na teren prawa zakonnego w miejsce zapomnianej egzempcji, stała się niejako nowym nośnikiem nadziei dla zakonnej niezależności ${ }^{37}$.

Abstrahując od przedstawionych wyżej krytycznych poglądów trzeba stwierdzić, że prawo słusznej autonomii, określone w kan. 586 , służy zachowaniu charyzmatu instytutów i chroni ich patrimonium, stanowi też obecnie naczelną zasadę regulującą relacje między Kościołem partykularnym a instytutami. Chociaż pojęcie autonomii jest nowe, to jednak sama zasada nie była obca życiu zakonnemu, a nawet niekiedy instytucję egzempcji utożsamiano $z$ autonomią. Dopiero użycie obu pojęć w trakcie przygotowań nowego Kodeksu pozwoliło na bliższe sprecyzowanie ich znaczeń ${ }^{38}$. Kanoniści zwracają rówież uwagę na różne pochodzenie egzempcji i autonomii. I tak pierwsza $z$ nich sięga korzeniami struktury chary-

${ }^{37}$ Por. R. Henselr, Podstawowe refleksje..., s. 24 i 28.

${ }^{38}$ Niestety obecnie, po promulgacji Kodeksu, nie ma zgodności co do relacji między egzempcją a autonomią. Zđaniem większości kanonistów prawa, które posiadaly instytuty wyjęte na mocy przywileju egzempcji, dziś są przyznane wszystkim instytutom kleryckim na prawie papieskim w wyniku autonomii. A zatem dawne przywileje obowiązują nadal. Pozostaje także egzempcja, lecz w innym kształcie - jako zasada ogólna odnosząca się do wladzy papieża. W KPK nie mówi się już o instytutach wyjętych, a ich zależność od hierarchii w kwestii życia wewnętrznego i apostolatu, reguluje się wedlug zasady autonomii lub zależności od władzy papieża albo ordynariusza miejsca. Inni autorzy twierdzą, że egzempcja nadal obowiązuje i ma różny zasięg w różnych instytutach oraz że należy ją odróżniać od autonomii. W tym względzie por. De Paolis, La vita consacrata..., s. 135 136; B.W. Zubert, Instytuty życia konsekrowanego i stowarzyszenia życia apostolskiego, Komentarz do Kodeksu Prawa Kanonicznego, Księga II. Lud Boży, Lublin 1990, s. 65; J. Beyer, Il diritto della...,s. 112; G. Ghirlanda, La vita consacrata nella vita della Chiesa, Informationes SCRIS 10/2/1984/90. 
zmatyczno-instytucjonalnej Kościoła i jest w związku z tym prawem wrodzonym instytutów, niezbywalnym i nienaruszalnym. Egzempcja natomiast ma swe źródło w prymacie papieża i w odróżnieniu od autonomii może zostać odwołana przez tę samą władzę, która ją przyznała.

Wracając do autonomii trzeba powiedzieć, że oznacza ona niezależność instytutów - zarówno na prawie papieskim, jak i diecezjalnym - od ordynariuszy miejsca, Konferencji Episkopatu oraz innej zewnętrznej władzy kościelnej niższej od Biskupa Rzymu. Nie oznacza ona jednak wcale całkowitej niezależności od władzy kościelnej, gdyż w Kościele nie jest możliwa tak pojęta niezależność. Ponadto żaden instytut nie jest samowystarczalny, lecz stanowi społeczność korzystającą ze środków Kościoła i ma sens tylko wtedy, kiedy jest włączony w życie organizmu Kościola partykularnego i powszechnego, w przeciwnym wypadku traci swój kościelny sens ${ }^{39}$. Jednak w granicach obowiązującej i koniecznej zależności istnieje możliwość autonomii zapewniającej instytutowi dużą swobodę działania, dzięki której może on regulować własne życie, interpretować dziedzictwo duchowe, realizować cel apostolski i tworzyć własne normy. Autonomia nie obejmuje więc całości życia w instytucie, lecz jedynie te sprawy, dla których nie została wyraźnie przewidziana przez prawo interwencja zewnętrznej władzy kościelnej. Chociaż istnieje pewna stopniowość autonomii w odniesieniu do instytutów na prawie papieskim i diecezjalnym, instytutów kleryckich i świeckich, to jednak cieszy się nią każdy z nich, ponieważ wypływa ona $z$ charyzmatów, które są udziałem wspólnot życia konsekrowanego. Charyzmat udzielony instytutowi dla dobra całego Kościoła domaga się autentycznego, tj. zgodnego z inspiracją Ducha Św., włączenia danego instytutu w życie wspólnoty Ludu Bożego. Stąd właśnie wynika obowiązek rozpoznania, zatwierdzenia i utrzymania przez hierarchiczną władzę kościelną charyzmatów w takiej postaci, w jakiej zostały udzielone. Uzasadnia się w ten sposób również prawo poszczególnych instytutów do autonomii sprzyjającej właściwej realizacji otrzymanego charyzmatu ${ }^{40}$.

\footnotetext{
${ }^{39}$ Por. M. Al. Zurowski, Spoteczności realizacji..., Prawo Kanoniczne 25/1982/ nr 1-2, s. 129.

4i" Por. A. Calabrese, Istituti di vita consacrata e societa di vita apostolica, Citta del Vaticano 1997, s. 39.
} 
Autonomię, o której mowa, prawodawca określił mianem ,słusznej” $\mathrm{z}$ dwóch powodów. Po pierwsze dlatego, że wiąże się ona z charyzmatyczną naturą instytutów i dla właściwego przeżywania charyzmatu słusznie im się należy. Po drugie dotyczy ona relacji do władzy hierarchicznej, gdyż instytuty, działające zawsze w imieniu Kościoła i w łączności $z$ nim, powinny okazywać należny szacunek prawowitym pasterzom $w$ granicach określonych prawem ${ }^{41}$.

Uznanie w obecnym Kodeksie słusznej autonomii każdego instytutu chyba najbardziej pozwala zachować i rozwijać własny charyzmat i dziedzictwo. W relacjach zaś pomiędzy instytutami życia konsekrowanego i stowarzyszeniami życia apostolskiego a Kościołem partykularnym istotne są dwie sprawy: pożytek Kościoła partykularnego oraz zachowanie własnego charakteru poszczególnych instytutów. To $\mathrm{z}$ kolei domaga się stosowania zasady poszanowania autonomii i wspóldziałania.

\subsection{Konieczność wzajemnej współpracy}

Kościól powszechny nie jest sumą czy federacją Kościolów partykularnych $^{42}$, lecz każdy $z$ nich stanowi pełne uobecnienie jednego i jedynego Kościola Chrystusowego. Dlatego też instytuty we wspódziałaniu z pasterzami Kościołów partykularnych powinny zmierzać do tego, aby wyrażać cały Kościół oraz wypełniać właściwą danemu instytutowi misję $z$ uwzględnieniem właściwości kulturowych danego regionu lub narodu. Tak jak wartości Kościoła powszechnego wzbogacają Kościoły partykularne, tak z drugiej strony wartości Kościołów partykularnych wzbogacają Kościól powszechny. Ten skomplikowany proces wzajemnego komplementarnego oddziaływania wymaga jednak współpracy biskupów i zakonników. Do biskupów należy prawidłowa ocena roli miejscowych wartości kulturowych i społecznych dla życia i rozwoju ich własnych Kościołów partykularnych, zakonnicy zaś powinni uważać się za członków rodziny Koścoła partykularnego poczuwać się do odpowiedzialności za niego i być gotowymi do koniecznych dla tego dzieła przystoso-

${ }^{41}$ Por. G. Pasquale, Autonomia e corresponsabilita dei religiosi nel Codex Iuris Canonici, Commentarium pro Religiosis et Missionariis 76/1995/279; G. Ghirlan$\mathrm{da}$, La giusta autonomia e l'esenzione degli istituti religiosi: fondamenti ed estensione, Vita consacarta 25/1989/679-699.

${ }^{42}$ Por. Evangelii nuntiandi, n. 62. 
wań. Przez swoją konsekrację są oni całkowicie wolni i mogą opuścić wszystko, by głosić Ewangelię, dlatego też do nich w pierwszym rzędzie należy podejmowanic nowych i oryginalnych inicjatyw apostolskich, a nawet eksperymentów w Kościele i danym regionie kościelnym. Jednak koordynacja tych różnorodnych inicjatyw, jeśli mają być one owocne, należy w zasadzie do trzech ośrodków: Stolicy Apostolskiej, pasterza Kościoła partykularnego i w odpowiednim zakresie do Konferencji Biskupów. Wymaga to oczywiście współpracy hierarchii kościelnej i instytutów na wszystkich wyżej wymienionych poziomach. Celowi temu służyć powinny Rady Przelożonych Generalnych i Wyższych, zarówno na szczeblu uniwersalnym jak i lokalnym ${ }^{43}$.

Rola biskupa polegać będzie przede wszystkim na roztropnym odczytywaniu znaków czasu, to znaczy tego, co Duch św chce ujawnić poprzez inicjatywy instytutów i stowarzyszeń życia apostolskiego w obrębie powierzonego mu Kościoła partykularnego. Zadanie to wykona on pozostając w stałym kontakcie i dialogu $\mathrm{z}$ instytutami. Dla samych zaś zakonników biskup jest nie tylko pasterzem Kościoła partykularnego, ale także gwarantem ich własnego powołania do służby w tymże Kościele. Stąd zakonnicy powinni pamiętać, że obowiązują ich normy, dekrety i zarządzenia biskupa dotyczące różnego rodzaju dzieł apostolskich, a także szczególnego typu działalności duszpasterskiej lub społecznej nakazanej lub zalecanej przez niego ${ }^{44}$.

Dobrze się stało, iż w celu koordynacji wspomnianej współpracy utworzono w wielu Kościołach partykularnych urząd wikariusza biskupiego dla instytutów życia konsekrowanego i stowarzyszeń życia apostolskiego. Jego obowiązkiem jest wspomaganie biskupa w czuwaniu nad życiem konsekrowanym w diecezji i włączanie go w pasterskie posługiwanie w Kościele partykularnym. Wikariusz ten powinien chętnie korzystać z pomocy doradców, którymi mogą, a nawet powinny być, osoby konsekrowane: kapłani, bracia oraz siostry zakonne.

Aby wspomniana współpraca była harmonijna, należy odróżniać dzieła apostolskie właściwe instytutom od dzieł zleconych s. 92 .

${ }^{43}$ Por. F. St. Pasternak, Wzajemne relacje..., Prawo Kanoniczne 22/1979/ nr 3-4,

${ }^{4}$ Por. Motu proprio Ecclesiae Sanctae, I, 25. 
im przez biskupa. Pierwsze $\mathrm{z}$ nich podlegają przełożonym zakonnym zgodnie $z$ konstytucjami /chociaż w aspektach ściśle duszpasterskich biskupowi/, drugie natomiast zależą od biskupa, a szczegółowy zakres pracy, obsady personalnej i kwestii ekonomicznych $z$ tym związanych powinien być zawsze określany w pisemnej umowie.

\section{Ważniejsze kwestie szczególowe}

Jest rzecz niemożliwą poruszenie tutaj wszystkich kwestii z zakresu relacji Kościół partykularny - instytuty zycia konsekrowanego i stowarzyszenia życia apostolskiego, dlatego też ograniczę się tylko do wybranych, moim zdaniem ważniejszych, w których najbardziej ujawnia się $\mathrm{z}$ jednej strony zależność, $\mathrm{z}$ drugiej zaś autonomia instytutów.

\subsection{Zakładanie i znoszenie instytutów życia konsekrowanego i stowarzyszeń życia apostolskiego, prowincji oraz domów}

Sposób powstawania oraz znoszenia instytutów jest zależny od tego, czy dany instytut jest na prawie papieskim czy też na prawie diecezjalnym ${ }^{45}$. Dla pełnej jasności należy tutaj brać pod uwagę również postanowienie kan. 605, mocą którego uprawnienie do zatwierdzania nowych form życia konsekrowanego zostało zarezerwowane jedynie Stolicy Apostolskiej. Wydaje się jednak, iż uprawnienie to zostało równocześnie delegowane biskupom diecezjalnym w przypadku instytutów na prawie diecezjalnym po uzyskaniu ,nihil obstat" tejże Stolicy Apostolskiej. Taki wniosek może wynikać z treści kan. 579, w którym prawodawca stanowi, że biskupi diecezjalni mogą - każdy na własnym terytorium - erygować formalnym dekretem instytuty życia konsekrowanego po niezbędnej konsultacji ze Stolicą Apostolską, co ma na celu rozpoznanie autentyczności charyzmatu i jego użyteczności dla Kościoła. Niezbędność wspomnianej konsultacji, warunkującej delegację udzieloną biskupowi, wyraża słowo "dummodo" zawarte w tekście lacińskim tego

${ }^{45}$ Por. Kan. 589: „Inystytut życia konsekrowanego nazywa się instytutem na prawie papieskim, jeśli został erygowany przez Stolicę Swiętą albo otrzymał od niej formalny dekret zatwierdzający. Jest natomiast na prawie diecezjalnym, gdy został erygowany przez biskupa diecezjalnego, a nie otrzymal od Stolicy Apostolskiej dekretu zatwierdzającego". 
kanonu ${ }^{46}$. Tak więc Stolica Apostolska posiadając kompetencje erygowania nowych instytutów, to jednak najczęściej pozostawia inicjatywę w tym względzie biskupom, ponieważ mogą oni z bliska śledzić proces formowania się nowego instytutu i pozostawać w kontakcie z założycielem.

Kanoniczne erygowanie instytutu następuje w momencie wydania przez biskupa dekretu erekcyjnego. Jednocześnie są zatwierdzane konstytucje mające najczęściej charakter czasowy /ad experimentum/, które zawierają także wcześniejsze wskazówki Stolicy Apostolskiej. Biskup może zmieniać normy w nich zawarte, $\mathrm{z}$ wyjątkiem jednak tych elementów dotyczących życia instytutu, które wcześniej zostały uzgodnione ze Stolicą Apostolską. A zatem biskup diecezjalny może erygować nowe instytuty życia konsekrowanego i stowarzyszenia życia apostolskiego i dopóki nie uzyskają one, pełnego zatwierdzenia Stolicy Apostolskiej - co następuje po spełnieniu wymaganych przez prawo warunków - podlegają jego władzy w zakresie określonym w kan. $594^{47}$. Szczegółowe uprawnienia biskupa diecezjalnego względem tego typu instytutów zawiera kan. $595^{48}$, a inne przepisy Kodeksu przyznają mu jeszcze szereg dodatkowych uprawnien ${ }^{49}$.

${ }^{46}$ Wśród kanonistów nie ma zgodności co do ważności erekcji instytutu w przypadku braku konsultacji ze Stolicą Apostolską. Część z nich uważa, że taki brak pociąa za sobą nieważność samej erekcji, ponieważ partykuła „dummodo" zamieszczona w kan. 579 zgodnie z kan. 39 dodaje warunek do aktu administracyjnego wymagany do ważności. /Por. L. Chiappetta, Il Codice di Diritto Canonico. Commento giuridico-pastorale, t. I, Roma 1996, s. 720; F. St. Pasternak, Ordynariusz miejsca..., s. 101, przyp. 8/. Inni autorzy z kolei są odmiennego zdania, argumentując swoje stanowisko tym, iż norma kan. 579 nie dotyczy aktu administracyjnego lecz prawnego, stąd też w przypadku erekcji instytutu nie można tłumaczyć jej nieważności, powołując się na kan. 39. Ponadto zgodnie $\mathrm{z}$ kan. 10 tylko te ustawy są nieważne, które postanawiają, że akt prawny jest nieważny, natomiast omawiany kanon takiej klauzuli nie zawiera. /Por. J. R. Bar, J. Kalowski, Prawo o instytutach życia konsekrowanego, Warszawa 1985, s. 52/.

${ }^{47}$ „Instytut na prawie diecezjalnym pozostaje, z zachowaniem kan. 586, pod szczególną opieką biskupa diecezjalnego".

${ }^{48}$ \$1: „Do biskupa, w którego diecezji znajduje się dom główny, należy zatwierdzanie konstytucji $i$ potwierdzanie prawnie wprowadzonych $w$ nich zmian, z zachowaniem wszakże tego, do czego przyłożyła rękę Stolica Apostolska. Należy do niego również zalatwianie ważniejszych spraw, dotyczących calego instytutu, a przekraczających komptencję wladzy wewnętrznej...”. \$2: „Biskup diecezjalny może w poszczególnych przypadkach dyspensować od przepisów konstytucji”.

${ }^{49}$ Por. KPK, kan. $609 \S 1 ; 625 \S 2 ; 628 \$ 2 ; 630 \S 3 ; 637 ; 638 \S 1$ i $4 ; 644 ; 645 \S 2$; 672 , ponadto $285 \S 4 ; 286 ; 287 \S 2 ; 289$, a także $675 \S 3 ; 678 ; 679 ; 688 \S 2 ; 691 \S 2$; $700 ; 727 ; 729 ; 733$ i 738 . 
Po tym ogólnym naświetleniu zależności instytutów na prawie diecezjalnym $w$ ich kanonicznym erygowaniu oraz działalności od biskupa diecezjalnego, należy wskazać na sytuację prawną instytutów i stowarzyszeń na prawie papieskim. Instytuty te po uzyskaniu pełnego zatwierdzenia przez Stolicę Apostolską i wyjęciu ich w określonych przez prawo wypadkach spod władzy biskupa diecezjalnego - co oznacza bezpośrednią zależność w zakresie wewnętrznego zarządu i dyscypliny od Stolicy Apostolskiej - pozostają mimo to nadal w określonych zależnościach od biskupa diecezjalnego. Dotyczy to w mniejszym stopniu instytutów kleryckich na prawie papieskim, które mają większą wewnętrzną autonomię, a ich przełożeni posiadają kościelną władzę rządzenia ${ }^{50}$, w większym zaś instytutów świekich.

Instytuty na prawie papieskim są najpierw uzależnione od biskupa w kwestii erygowania nowego domu na terenie danej diecezji, bo chociaż możliwość założenia domu zapewnia przyznana instytutom autonomia, to jednak do jej realizacji konieczna jest pisemna zgoda biskupa, przy czym na erygowanie klasztoru mniszek wymaga się zezwolenia Stolicy Apostolskiej ${ }^{51}$. Treść kan. 609 mogłaby pozornie wskazywać na pewne ograniczenie wolności kompetentnej władzy instytutu $\mathrm{w}$ podejmowaniu decyzji o erygowaniu nowego domu. Obawy te jednak znikają, gdy weźmie się pod uwagę kan. $586 \$ 2$. Wynika $\mathrm{z}$ niego, że biskup powinien współdziałać $\mathrm{z}$ kompetentnym przełożonym $\mathrm{i}$ być zaintersowany tym, aby instytut $\mathrm{w}$ nowo powstałym domu mógl wiernie realizować swój cel i pomnażać swoje dziedzictwo. Wyrażając jednak zgodę na zamieszkanie zakonników na terenie jego diecezji, biskup musi uwzględniać również pożyteczność danego instytutu dla Kościoła partykularnego. Jeżeli okaże się np., że inne instytuty o podobnej działalności wystarczająco zaspokajają potrzeby powierzonego mu Kościoła, biskup może nie chcieć utworzenia nowego domu. Podobnie jeśli biskup wyraża zgodę na założenie domu, ale proponowane przez niego warunki nie odpowiadają celowi instytutu, wówczas ostateczna decyzja należy do przełożonych zakonnych.

Pozwolenie biskupa jest równoznaczne z zezwoleniem na prowadzenie życia zgodnego $\mathrm{z}$ celem $\mathrm{i}$ charakterem instytutu oraz na pro-

\footnotetext{
${ }^{50}$ Por. KPK, kan. $596 \$ 2$.

${ }^{51}$ Por. KPK, kan. 609.
} 
wadzenie własnych dzieł ${ }^{52}$, posiadanie własnej kaplicy z Najśw. Sakramentem ${ }^{53}$ oraz posiadanie kościola /w przypadku instytutów kleryckich/ i wykonywanie w nim świętych posług zgodnie $z$ przepisami prawa ${ }^{54}$. Zgoda biskupa jest wymagana także w sytuacji przeznaczenia domu zakonnego na prowadzenie dziel apostolskich innych od tych, dla których dom został ustanowiony ${ }^{55}$.

W kwestii znoszenia instytutów, prowincji oraz domów uzależnienie od biskupa diecezjalnego jest minimalne - dotyczy tylko domów i to w bardzo ograniczonym zakresie, ponieważ należy jedynie zasięgnąć rady biskupa diecezjalnego ${ }^{56}$.

\subsection{Działalność apostolska}

Działalność apostolska instytutów należy do ich natury i wynika $z$ ich integralnej przynależności do Ludu Bożego oraz ścisłego włączenia w misję apostolską Kościoła. Powinna ona być realizowana z uwzględnieniem dwóch ważnych zasad - posłuszeństwa pasterzowi diecezji, któremu na mocy urzędu przysługuje rola pasterza Kościoła partykularnego, a także zasady zachowania wierności charakterowi i tradycjom instytutu, duchowi i celom założyciela, a więc własnemu dziedzictwu ${ }^{57}$. Zachowaniu równowagi między wyżej wskazanymi zasadami sprzyja autonomia, której nie można ograniczać jedynie do życia wewnętrznego instytutu, ponieważ wówczas nie wystarczylaby do zachowania jego tożsamości, a także charyzmatyczna natura instytutów, gdyż charyzmat promieniuje na zewnątrz. Przejawem troski Kościola o prowadzenie apostolatu zgodnego $\mathrm{z}$ charakterem instytutu jest postanowienie kan. $678 \S 2$ który odpowiedzialnść za to składa na biskupów. Nie mogą więc oni nakładać na zakonników dzieł apostolskich niezgodnych z charyzmatem instytutu. Jako gwaranci autonomii mają natomiast obowiązek

\footnotetext{
${ }^{52}$ Por. KPK, kan. 611.

${ }^{53}$ Por. KPK, kan. 608. Dotyczy to także instytutów świeckich, jeśli prowadzą życie wspólne, oraz stowarzszeń życia apostolskiego/por. kan. 719 i 733 \$2/.

${ }^{54}$ Por. KPK, kan. 611. Jednak na budowę kościoła w ściśle określonym miejscu wymagane jest ponowne pozwolenie biskupa diecezjalnego /por. kan. $1215 \$ 3$. .

3 Por. KPK, kan. 612.

${ }^{56}$ Por. KPK, kan. $616 \$ 1$.

${ }^{57}$ Por. KPK, kan. 676, 677, 678. Szerzej na ten temat por. B. W. Zubert, Apostolstwo zakonników i jego wlaczenie w ogólna dziatalność duszpasterska Kościoła partykularnego, w: Autonomia zakonów a Kościół partykularny, Lublin 1991, s. $31-52$.
} 
poznawać specyfikę instytutów i stowarzyszeń życia apostolskiego działających na terenie ich diecezji i troszczyć się o to aby były jej wierne w swej działalności.

W praktyce precyzyjne określenie granic kompetencji biskupów i przełożonych zakonnych $w$ dziedzinie apostolatu bywa jednak trudne, gdyż zakonnicy podlegają zarówno swoim przełożonym, jak też biskupowi. $Z$ jednej strony mają uznawać zwierzchnictwo biskupa Kościoła partykularnego, $z$ drugiej zaś powinni być świadomi tego, że ich działalność apostolska należy do natury instytutu i odznacza się specyficznym rysem. Aby uniknąć nieporozumień, konieczna jest stała wspólpraca między ordynariuszem miejsca a przełożonymi zakonnymiss, uwzględniająca fakt, że specyfika każdego instytutu wyrażająca się również w apostolacie, ma służyć dobru Kościola, w tym także partykularnego. Uporządkowana wspólpraca i koordynacja wymagają m.in. respektowania kompetencji drugiej strony oraz przestrzegania zasady partnerstwa. Zakonnicy w swojej działalności apostolskiej nie mogą być jedynie wykonawcami decyzji podjętych odgórnie, bez ich udziału, komunikowanych im w sposób imperatywny. Takie formy - dziś zresztą nierzadkie - będące naruszeniem nie tylko litery, ale i ducha prawa, udaremniają wspólpracę. To z kolei rodzi postulat, aby zapewnić księżom zakonnym proporcjonalny udział w Radzie Kapłańskiej, a braciom i siostrom zakonnym - w Radzie Duszpasterskiej lub w innych instytucjach Kościoła partykularnego. Na tym tle co najmniej dziwne wydają się np. postanowienia Konferencji Episkopatu Polski dotyczące nadzwyczajnego szafarza Komunii św. I tak brat zakonny, aby mógł pełnić tę funkcję powinien mieć ukończone 30 lat i posiadać przynajmniej średnie wykształcenie, a siostrom zakonnym w ogóle nie wolno pełnić tej posługi ${ }^{59}$. Obecnie nie do przyjęcia jest koncepcja pracy apostolskiej w izolacji, bez jej koordynacji na terenie Kościoła partykularnego ${ }^{6 / 1}$ oraz bez angażowania w nią wszystkich poświęcających się działalności apostolskiej. Należy również przypomnieć, że do posług duszpasterskich względem wiernych nawet we wła-

\footnotetext{
${ }^{58}$ Por. KPK, kan. $678 \$ 3$.

50) Por. Konferencja Episkopatu Polski, Postanowienia odnośnie do nadzwyczajnego szafarza Komunii św., 2.5.1990, w. Dokumenty duszpastersko-liturgiczne Episkopatu Polski 1966-1998, Lublin 1999, s. 64-65.

${ }^{2}$ Por. B. W. Zubert, Apostolstwo zakonników..., s. 50-51.
} 
snych kościołach zakonnicy muszą otrzymać od ordynariusza miejsca tzw. misję kanoniczną, czyli upoważnienie do głoszenia słowa Bożego, do sprawowania celebracji eucharystycznych oraz sakramentu pokuty ${ }^{61}$. Jeżeli zaś otrzymają wraz z powierzonym urzędem habitualne upoważnienie do spowiadania jest ono ważne wszę$\mathrm{dzic}^{62}$. W związku z powyższym należy również zwrócić uwagę na kwestię prezentacji.

\subsection{Zagadnienie prezentacji}

W relacjach między Kościołem partykularnym a instytutami życia konsekrowanego - zwłaszcza w dziedzinie apostolatu - prezentacja na urząd, czy do wypełnienia jakiegoś zadania w diecezji wydaje się być środkiem praktycznym ułatwiającym rozwiązywanie wielu problemów. Obowiązujący Kodeks w oparciu o smutne doświadczenia historyczne zniósł wszelkie prezentacje zewnętrzne na urzędy kościelne dopuszczając jedynie prezentacje ściśle wewnątrzkościelne. W relacjach między biskupem a wyższym przełożonym zakonnym prezentacja $w$ dalszym ciągu jest aktualna ${ }^{63}$. Tak więc zakonnik otrzymuje nominację na jakiś urząd w diecezji, od biskupa diecezjalnego po przedstawieniu kandydata przez kompetentnego przełożonego lub przynajmniej za jego zgodą ${ }^{64}$. Kompetentny przełożony $z$ kolei powinien przedstawić jednego lub kilku kandydatów, zdatnych do sprawowania danego urzędu, w ciągu trzech miesięcy od otrzymania wiadomości o wakansie urzędu ${ }^{65}$. Jeśli przełożony przedstawił kandydata niezdatnego, a zdatność tę ocenia biskup zgodnie $\mathrm{z}$ prawem powszechnym czy partykularnym, wówczas w ciągu miesiąca przełożony może zaprezentować innego kandydata. Jeśliby jednak przełożony dwukrotnie prezentował kandydata niezdatnego, traci prawo do prezentacji, a biskup może powierzyć urząd w sposób swobodny. Pojawia się tu jednak pewna trudność. Otóż w przypadku gdy np. parafia została powierzona $^{66}$ instytutowi na stałe lub gdy chodzi o zakonny kościół rek-

\footnotetext{
${ }^{61}$ Por. KPK, kan. 903 i 969.

${ }^{62}$ Por. Tamże, kan. $967 \S 2 ; 971$ i 972.

${ }^{63}$ Por. KPK, kan. $158 \$ 1$.

${ }^{64}$ Por. Tamze, kan. $682 \S 1$.

${ }^{65}$ Kandydat lub kandydaci powinni być zapytani o zgodę, którą winni wyrazić w ciagu 8 dni /por. kan. 159/.

wi Por. KPK, kan. 520.
} 
torski ${ }^{67}$ biskup mimo posiadanego uprawnienia do swobodnego powierzania urzędu nie może $z$ tego uprawnienia skorzystać bez zgody kompetentnego przełożonego zakonnego.

Zakonnik, który otrzymał nominację od biskupa diecezjalnego po przedstawieniu go przez kompetenetnego przełożonego lub przynajmniej za jego zgodą, może być usunięty z powierzonego urzędu przez powierzającego urząd po powiadomieniu przełożonego zakonnego, a także przez przełożonego po powiadomieniu nadającego, bez jego zgody ${ }^{68}$.

\subsection{Inne obszary zależności i wspólpracy}

Z dotychczasowych rozważań można wysnuć wniosek, że prawodawca kodeksowy uzależnia instytuty życia konsekrowanego i stowarzyszenia życia apostolskiego od biskupa diecezjalnego w wielu przejawach ich egzystencji: powstanie, rozwój i całą działalność pastoralną. Należy jednäk zauważyć, że kompetencja biskupa oraz jego współpraca $z$ instytutami ujawnia się również w innych obszarach. Zalicza się do nich przede wszystkim kult publiczny, wizytacje oraz kwestie dyscyplinarne.

W Kościele partykularnym do biskupa diecezjalnego należy obowiązek czuwania nad sprawowaniem kultu Bożego, sakramentów św. i posługą słowa. Biskupi - jako główni szafarze Bożych tajemnic oraz moderatorzy, stróże i promotorzy życia liturgicznego - posiadają w tym względzie wyłączną władzę w powierzonym sobie Kościele. Członkowie insytututów i stowarzyszeń, którzy sprawują kult publiczny zarówno w swoich kościołach, jak i w kaplicach domów zakonnych są całkowicie zależni od tej władzy ${ }^{69}$. Zależność tę uzasadnia wystarczająco spójność i jedność dyscypliny kościelnej, bowiem instytuty realizują swoją autonomię w Kościele, nie zaś wobec niego

Również wizytacja należy do pasterskich obowiązków biskupa diecezjalnego. Podlegają jej instytuty i stowarzyszenia, chociaż nie wszystkie w jednakowym stopniu. I tak instytuty na prawie papieskim, zgodnie z kan. 397 biskup może wiyzytować w przypadkach przewidzianych przez prawo ${ }^{70}$. Normę cytowanego kanonu należy

\footnotetext{
${ }^{67}$ Por. KPK, kan. 556 i $557 \S 2$.

${ }^{68}$ Por. KPK, kan $682 \$ 2$.

${ }^{69}$ Por. Tamże, kan. $678 \$ 1$.

${ }^{7}$ Por. KPK, kan. 397 §2.
} 
postrzegać w kontekście kan. 593, który stanowi, że instytuty te podlegają bezpośrednio i wylącznic Stolicy Apostolskiej w zakresie wewnętrznego zarządu i dyscypliny. Jednak na mocy kan. 683 nadzorowi i wizytacji biskupa diecezjalnego zostały poddane te kościoły i kaplice należące do instytutów na prawie papieskim, do których wierni uczęszczają habitualnie. Ponadto wizytacji biskupiej podlegają szkoły oraz inne dzieła religijne lub miłosierdzia duchowego powierzone zakonnikom, z wyjątkiem szkół dostępnych wyłącznie własnym alumnom instytutu. Natomiast instytuty i stowarzyszenia na prawie diecezjalnym oraz klasztory niezależne ${ }^{71}$ biskup może wizytować także w zakresie dyscypliny zakonnej.

Należy zauważyć, że biskup diecezjalny może także nakazać przeprowadzenie specjalnej zbiórki na określony cel we wszystkich kościołach i kaplicach, nawet należących do instytutów i stowarzyszeñ $^{72}$. Z drugiej strony wszelkie zbieranie ofiar, w tym także przez zakonników, wymaga pisemnej zgody własnego ordynariusza i ordynariusza miejsca ${ }^{73}$.

$\mathrm{Na}$ koniec należy również wspomnieć o ograniczeniu wynikającym z kan. 679, który stanowi, że biskup diecezjalny, gdy przynagla go do tego bardzo poważna przyczyna, może zabronić członkowi instytutu lub stowarzyszenia przebywania na terenie jego diecezji.

\section{Zakończenie}

Z przedstawionych rozważań wynika, że instytuty życia konsekrowanego i stowarzyszenia życia apostolskiego, włączone integralnie w Kościół i jego misję, powinny też podlegać kościelnej władzy hierarchicznej oraz być włączone $\mathrm{w}$ określone prawem struktury ustrojowe Kościoła. Słuszna autonomia i współdziałanie tworzą więc plaszczyznę na której powinny być regulowane relacje między Kościołem partykularnym a instytutami i stowarzyszeniami. Ich wkład w działalność apostolską Kościoła był i jest olbrzymi, a rozpatrywana na tym tle prawna ingerencja władzy kościelnej nie powinna być pojmowana jako ograniczenie, lecz jako wyraz troski Kościola o ich odnowę i rozwój, zwłaszcza zaś dostosowywanie życia i działalności instytutów oraz stowarzyszeń do własnego dziedzic-

\footnotetext{
${ }^{7}$ Por. KPK, kan. $628 \S 2$ i 615.

${ }^{72}$ Por. KPK, kan. 1266.

${ }^{73}$ Por. KPK, kan. 1265.
} 
twa duchowego. Relacje, o których mowa, powinny być oparte na dwóch zasadach: szacunku względem biskupa diecezjalnego ze strony instytutów i poszanowaniu słusznej autonomii ze strony biskupów diecezjalnych. W tym też kontekście ukazywane są relacje pomiędzy instytutami i stowarzyszeniami a władzą Kościola partykularnego w dokumentach. Zasady powyższe powinny być uwzględniane podczas rozwiązywania wszelkich problemów dotyczących relacji między Kościołem partykularnym a instytutami życia konsekrowanego i stowarzyszeniami życia apostolskiego.

\section{L'Eglise particulière envers Les Instituts de Vie Consacrée et Les Sociétés de Vie Apostolique}

Les relations mutuelles entre l'Eglise particulière et les instituts de vie consacrée ansi que les sociétés de vie apostolique, leur forme canonique étaient soumis aux changements selōn les conditions de leur temps. Dans certains périodes de l'histoire de l'Eglise elles se caractérisaient par certaines tensions, même aujourd'hui ce problème possède plusiers aspects qui sont a l'origine des collisions pratiques compétitives entre les évêques et les supérieurs religieux.

Lauteur concentre sur deux problems importants. D'abord les bases théologique et juridique des relations mutuelles et dans le cadre de ce thème il parle des questions suivantes: la nature de l'Eglise particulière, la spécificité des instituts de la vie consacrée et de sociétés de vie apostolique, le problème d'exemption, l'autonomie légitime, la nécessité de collaboration mutuelle. Ensuite les questions détaillées plus importantes et parmi elles il rappele la fondation et la suppression de instituts de vie consacrée et des sociétés de vie apostolique, des provinces et des maisons, le problème de l'activité apostolique des religieux, la question de la présentation ainsi que d'autres espaces de dépendance et de collaboration. 